FESIEE

Fundación Emilio Soldevilla para la Investigación y Desarrollo de la Economia de la Empresa

\section{Management Letters / Cuadernos de Gestión}

\author{
journal homepage: http://www.ehu.eus/cuadernosdegestion/revista/es/
}

ISSN: 1131-6837 / e-ISSN: 1988-2157

\title{
The identification-loyalty relationship in a university context of crisis: the moderating role of students and graduates
}

\section{La relación identificación-lealtad en un contexto universitario de crisis: el papel moderador de estudiantes y egresados}

\author{
Gabriel Cachón-Rodríguez ${ }^{*}$, Camilo Prado-Román ${ }^{\mathrm{a}}$ \\ a Universidad Rey Juan Carlos. Departamento de Economía de la Empresa, Universidad Rey Juan Carlos. Paseo de los Artilleros, 28032 Madrid (España) - camilo.prado. \\ roman@urjc.es - https://orcid.org/0000-0002-1540-0643
}

* Corresponding author: Universidad Rey Juan Carlos. Departamento de Economía de la Empresa. Universidad Rey Juan Carlos. Paseo de los Artilleros s/n, 28032 Madrid, España-gabriel.cachon@urjc.es-https://orcid.org/0000-0002-4228-2881

\section{A R T I C L E I N F O}

Received 15 April 2019,

Accepted 18 November 2019

Available online 31 July 2020

DOI: $10.5295 / \mathrm{cdg} .191109 \mathrm{gc}$

JEL CODE: I23, M31

\begin{abstract}
A B S T R A C T
The aim of this study is to analyse the relationship between identification and loyalty in a public higher education institution in an institutional crisis context. In addition, the differences regarding the possible moderating effect that two of its main stakeholder categories can have on this relationship are studied, which are students and graduates. The information needed to conduct the empirical analysis was obtained from an online survey. Data processing was carried out using the PLS-SEM technique. The results show that in a context of institutional crisis, identification influences university loyalty positively and significantly. However, the existence of certain differences between the two stakeholder categories considered is detected, with the moderating effect being more intense in the group of students than in the group of graduates. It is a useful contribution as it is one of the first studies in which the proposed relationships are analysed in a context of organizational crisis and, in addition, it is concerned with investigating the possible existence of differences in the moderating role played by two fundamental stakeholder categories. This contribution becomes more significant when comparing the moderating effects by using two non-parametric methods (PLS-MGA and permutations), which compared to other techniques have significant advantages to examine the proposed relationship. Important practical implications arise from the results of this work, which can be particularly useful for managers of the type of organisations analysed.
\end{abstract}

Keywords: Higher education, identification, loyalty, institutional crisis, measurement invariance, multigroup analysis.

R E S U M E N

El objetivo de este trabajo es analizar la relación entre identificación y lealtad en una institución pública de educación superior en un contexto de crisis institucional. Asimismo, se examinan las diferencias respecto al posible efecto moderador que sobre dicha relación pueden desempeñar dos de sus principales categorías de stakeholders, como son los estudiantes y los egresados. La información necesaria para realizar el análisis empírico se ha obtenido mediante una encuesta on-line. El tratamiento de los datos se ha llevado a cabo mediante la técnica PLS-SEM. Los resultados obtenidos muestran que en un contexto de crisis institucional la identificación influye de forma positiva y significativa en la lealtad universitaria. No obstante, se detecta la existencia de ciertas diferencias entre las dos categorías de stakeholders consideradas, siendo el efecto moderador más intenso en el grupo de los estudiantes que en el de los egresados. Supone una contribución de utilidad al ser uno de los primeros trabajos en los que las relaciones propuestas se analizan en un contexto de crisis organizacional y que, además, se preocupa por indagar en la posible existencia de diferencias en el papel moderador ejercido por dos categorías fundamentales de stakeholders. Esta contribución se hace más significativa al comparar los efectos moderadores a través de dos métodos no paramétricos (PLS-MGA y permutaciones) que, frente a otras técnicas, presentan ventajas notables para examinar la relación propuesta. De los resultados del trabajo se derivan importantes implicaciones prácticas que pueden ser de especial utilidad para los gestores del tipo de organizaciones analizadas.

Palabras clave: Educación superior, identificación, lealtad, crisis institucional, invarianza de medida, análisis multigrupo. 


\section{INTRODUCTION}

In recent years, factors such as globalization, advances in new information and communication technologies, as well as the impact of the last major economic-financial crisis have created a more competitive environment, which higher education institutions (HEIs) have to face. In particular, the entry into operation of the European Higher Education Area, promoted by the so-called 'Bologna process', has the following three fundamental pillars: facilitating financing and access to higher education, promoting and attracting student mobility and teachers from other countries and improving employability. All these factors have contributed to the fact that HEIs can offer similar education services in different countries, so they can be forced to differentiate themselves in order to attract students (Pucciarelli and Kaplan 2016).

In this adaptation process, the Spanish public university system is becoming less competitive compared to the private system, as some statistics ensure. The number of private universities has increased fivefold in the last 20 years, representing $40 \%$ of the range of university studies (Pérez et al. 2017). The number of students that decide to study at a private university has also multiplied by five, from 52,000 to about 245,000 students enrolled in the $2016-17$ academic year, which represents $16.4 \%$ of university students studying in Spain compared to only $4 \%$ that studied 20 years ago (Pérez et al. 2017).

Identification and loyalty are considered key intangible assets for the survival of organizations in highly competitive environments and institutional crises, since they can make a difference (Sallam and Wahid 2015). Thus, organizations that have a good level of identification and loyalty achieve a stronger commitment and relationship with their stakeholders over time. Therefore, they can provide a competitive advantage (Kang et al. 2015), which will allow them to deal with an institutional crisis situation (Gistri et al. 2018).

In recent research, identification with the brand is shown as a variable whose direct impact on the attitude towards the organization and on the purchase intention is moderated by an organizational crisis situation (Johar et al. 2010; Gistri et al. 2018). On the other hand, loyalty is analysed from two approaches: a) as a variable that decreases in a crisis situation, that is, as an antecedent; and b) as a result variable, where a crisis situation can affect the loyalty level more due to the fact that the most loyal stakeholders have higher expectations (Ruan 2016).

The aim of this study is to respond to the following questions: First, is there a direct relationship between identification and loyalty during a crisis that affects the organization? In other terms, does identification help to create strong loyalty when faced by an adverse organizational situation? Second, can there be significant differences between the group of students and the group of graduates in this relationship? In other terms, can the relationship be moderated by these stakeholders?

To respond to these questions, this research has focused on an organizational crisis situation in a Spanish public university. In March 2018, the media brought to light a particular crisis case in the Spanish public system of higher education: the so-called "Master's Case", related to the Institute of Public Law - an independent organization attached to the University Rey Juan Carlos.
This Case had a great impact at national level due to the alleged irregularities observed when awarding some Master's degrees given by the Institute to several influential personalities, mainly in the area of politics. A priori, one might think that this crisis situation must have had consequences in terms of identification and loyalty for the affected university community, especially for two of its main stakeholder groups: students and graduates.

The original contribution of this study is reflected as follows. Although in some studies the relationship between both variables has been analysed, as far as we know, they have not been applied to an organizational crisis case and in addition, they have been limited to analysing a single stakeholder group; either students (Balaji et al. 2016), teachers (Takaki et al. 2015), or consumers in the business field (Coelho et al. 2018). These studies do not take into account if the intensity of the relationship of both variables, in an organizational crisis situation, could vary depending on the type of stakeholder considered: students and graduates. In this context, at a methodological level, the moderating effects are compared by using two non-parametric methods (PLS-MGA and permutations), which compared to other methods, have significant advantages to examine the proposed relationship.

The analysis of the groups of students and graduates in a university crisis is fundamental for different reasons. On the one hand, an increase in private institutions leads public institutions to adopt relational marketing strategies with students and graduates to ensure a closer relationship over time. On the other hand, as they are members with previous experiences regarding the institution, graduates' evaluations and opinions about the institution in a crisis situation can be key in recommending it to other types of stakeholders (Schlesinger et al. 2014).

The rest of the study is structured as follows. In the next section, the theoretical framework and hypotheses are proposed. Next, the methodology used and the results obtained are presented successively. The study ends with the conclusions, practical implications, limitations and future lines of research.

\section{THEORETICAL FRAMEWORK AND HYPOTHESES}

\subsection{Conceptual delimitation of identification and loyalty}

The social identity theory (Tajfel and Turner 1986) maintains that, on the one hand, an individual has features derived from social order by belonging to groups and, on the other hand, idiosyncratic attributes that are characteristic of that individual. Organizational identification is a form of social identification that occurs when a member's beliefs about the organization become a self-definition of himself. It involves a voluntary, active and selective relationship between the stakeholder and the organization, aimed at satisfying one or more of his personal definition needs (Bhattacharya and Sen 2003). Important bonds and links of the stakeholder with the organization are generated through this relationship, which help the stakeholder to achieve his objectives (Sen et al. 2015). In this regard, the university, which is considered an organization, is composed of a form of social identification that will contribute to meeting the needs of its different types of stakeholders, including differentiation, socialization or self-identity needs (Takaki et al. 2015). 
Identification has been analysed in previous research as an attitudinal element comprised of cognitive and affective elements (Ashforth et al. 2008). From a cognitive point of view, it is presented as a process of self-categorization or belonging of a stakeholder to an organization (Mael and Ashforth 1992). At emotional level, it refers to the commitment or emotional bond of the stakeholder with the organization (Ellemers et al. 1999). Most studies consider that identification is formed by cognitive and affective elements that complement each other. In this way, identification is not only a cognitive process of overlap or belonging between the stakeholder and the organization, but also a subjective (affective) feeling of social comparison between both identities (Bergami and Bagozzi 2000). This cognitive state will influence the affective states of stakeholders towards the organization and their subsequent behaviour towards it (Marín and Ruiz 2007).

The concept of loyalty has been examined from different approaches. On the one hand, the affective perspective (Bloemer and De Ruyter 1999), where a stakeholder can show preference towards a certain organization, although that feeling of affinity does not involve bonding behaviour. On the other hand, the aim of the behavioural perspective (Oliver 1999) is to analyse the influence that loyalty has on the real and repetitive behaviour of stakeholders towards a preferred organization. Other research combines both perspectives (behavioural and affective) in order to provide a more complete analysis of the feeling of loyalty of a certain type of stakeholder towards a specific organization (Coelho et al. 2018). At university level, loyalty also contains an attitudinal and behavioural component, and is positively related to the ability of a university to attract new students (Iskhakova et al. 2017) or graduates (Helgesen and Nesset 2007), making 'mouth to mouth' recommendations for future enrolments $(\mathrm{Ca}-$ sanoves et al. 2017) or even making donations (Stephenson and Yerger 2014) by their different types of stakeholders.

\subsection{Relationship between identification and loyalty in a crisis situation}

A crisis is an event which is perceived by stakeholders as relevant, unexpected and harmful, which can threaten the objectives of an organization and have profound implications for its relationships with its stakeholders (Bundy et al. 2017). Other studies define it as a perception of an unpredictable event that threatens stakeholders' important expectations, which can negatively affect the organization's performance or results (Coombs 2014).

The relationship between the identification of a type of stakeholder and a HEI represents an ideal state of relationships, which is more intense than simple loyalty or fidelity. This relationship causes different types of stakeholders to feel connected to the institution, speak well of it, attract new types of stakeholders or perform extra-role activities to achieve its objectives (Balaji et al. 2016). Identification differs from loyalty in that while identification is necessarily linked to the causes, objectives or values that the organization has and that the stakeholder shares with it, loyalty is the sum of perceptions that the stakeholder has of his own experiences (Cachón et al. 2019). For this reason, the different types of stakeholders identified with the organization will be more loyal to it during a crisis situation, while those types of stakeholders loyal to an organization do not have to feel identified with it in this kind of adverse situation (Marín and Ruiz 2007; Xiao and Lee 2014). Thus, a type of stakeholder can feel connected (identified) with an organization which is immersed in an institutional crisis even without having interacted with it, while loyalty requires previous contacts or experiences (Bhattacharya and Sen 2003; Balaji et al. 2016; Heffernan et al. 2018).

Different investigations have observed that a high level of identification can become an important asset for the organization as a whole, as it can contribute to increasing its market value through greater loyalty (Bhattacharya and Sen 2003; Tuškej et al. 2013). In a similar vein, other studies indicate that loyalty will be enhanced when different types of stakeholders become psychologically attached to the institution and are concerned about it (Balaji et al. 2016; Palmer et al. 2016); that is, they are previously identified with it. Identification causes behaviours which are characterized by courtesy, altruism and benevolence and implies that they may overlook certain negative or unexpected (crisis) information about an institution or brand (Gistri et al. 2018) and consequently, they can maintain or increase their level of loyalty to it (Bhattacharya and Sen 2003).

Therefore, from the above, we can expect that those university students and graduates who are more identified with it should show a more favourable attitude towards it in a crisis situation, which is revealed by a greater desire to stay in the university over time, to take different postgraduate courses, to recommend it to other people or even make donations (that is, to show true loyalty to it). Thus, the following hypotheses can be established:

Hypothesis 1: Identification of students and graduates positively influences loyalty to the university in a crisis situation.

According to the stakeholder theory (Freeman and Reed 1983), for organizations to achieve their different goals, they must achieve a balance between the objectives of different stakeholders and thus, achieve their survival. In this regard, detecting if there are significant differences between the category of students and graduates in the relationship between identification and loyalty will play a key role for HEIs to obtain competitive advantages in their strategic management of an institutional crisis.

The existence of differences between student and graduate categories regarding this relationship may arise due to several reasons. Graduates, unlike students, are users who have already had contact with HEIs, so their identification and loyalty are the result of their previous experiences. This circumstance can cause the relationship between identification and loyalty in a crisis situation to be evaluated differently, both in the generation of a lower sense of connection with it as in the social relevance of higher education. The fact that students are members who continue to be connected to HEIs may imply that their identification and loyalty are less stable or more vulnerable to certain behaviours or communications that the institution wants to convey in a crisis situation. The sources used to collect information about an event of this nature, which may affect a HEI could cause differences between graduates and students. As graduates are external agents, their information may come from more objective communication means, which causes a decrease in the relationship between identification and loyalty. As students' information comes from internal sources, it can be more subjective, causing 
greater intensity in the relationship between identification and loyalty. Therefore, we can establish:

Hypothesis 2: The relationship between identification and loyalty in a university in a crisis situation is moderated by the type of stakeholder: students and graduates. In addition, the effect of the relationship will be more intense in students than in graduates.

\section{METHODOLOGY}

\subsection{Research context}

The stated hypotheses in this research were tested in a context of organizational crisis that affected the University Rey Juan Carlos (URJC), as a consequence of the so-called "Master's Case".

The URJC is the second public university of the Madrid Autonomous Community by number of students, with a total of 38,958 students (Universidad Rey Juan Carlos 2018). It is among the 250 best universities in Europe according to the Europe Teaching Ranking of 2019, made by the prestigious organization Times Higher Education (2019). This classification recognizes and values the quality of education and teaching offered in European universities, based on the opinion of more than 125,000 students from 18 countries. It has managed to position itself among the best universities worldwide, in different areas in the Global Ranking of Academic Subjects (such as, for example, Ecology, Communication, Biological Sciences, Chemical Engineering, Computer Science and Engineering) of 2019, which is made by the Jiao Tong University of Shanghai, and is known as the 'Shanghai Ranking'. In addition, according to the QS Graduate Employability Ranking (2019) (QS Quacquarelli Symonds Limited 2019), it is among the top 11 universities in Spain and among the 300 in the world regarding the labour insertion rate of its graduates. Moreover, according to the VII Study on University Volunteering prepared by the Mutua Madrileña Foundation, it ranks second among Spanish universities in terms of number of volunteer initiatives launched during the 2018/2019 academic year, with a total of 192 volunteer initiatives promoted (Fundación Mutua Madrileña 2020). The latest study on Public Transparency of Spanish Universities positions it as the most transparent university in the Community of Madrid and in the fifth place, in terms of transparency of a total of 79 Spanish universities, both public and private (Dyntra 2020).

On $21^{\text {st }}$ March, 2018, a crisis situation affected this institution. The newspaper eldiario.es published a journalistic investigation on the establishment of a privileged mechanism for politicians and influential people to obtain postgraduate degrees in a public centre (Ejerique 2018). The investigation revealed that the president of the Community of Madrid could have obtained her Master's Degree in Autonomic Law given by the Public Law Institution (IDP) - an independent organization of the University Rey Juan Carlos-, in an alleged irregular situation, since falsifications were detected in some of her academic record grades of the 2011-2012 academic year. The journalistic investigation made students and graduates suffer a loss of identification and they demonstrated in front of the campuses. University associations reported the case to the Prosecutor's Office and the president of the Community of Madrid filed complaints for an offence against her honour. Finally, she was forced to resign from her post at the head of the Presidency of the Community.

The fact that students were one of the main affected groups was considered an injustice by them. This situation was reflected with a high impact on the national media and fuelling a great public debate, leading to a potential identification and institutional loyalty crisis. In addition, this case put a spotlight on the entire Spanish higher education sector.

Following the discovery of the poor functioning of the IDP, the URJC, at the request of its Rector, initiated an internal investigation and audit that has been extended for several months, also agreeing to create a new inspection regulation. The Governing Council of the university itself unanimously agreed to the dissolution and definite closure of this institute. The URJC also appeared as a private prosecutor in the subsequent trial.

\subsection{Data collection}

An online survey to collect the data was created by SurveyMonkey, which took place in May and June 2018, in the 5 weeks after the crisis. This process was carried out in two stages. In the first stage, a 'focus group' was established in which a professor, a vice-dean, a government position, three lecturers and two students related with the Department of Business Economics were involved to prepare a pre-test that was sent online to 300 students in order to check that the questions were clear, that the application was setup correctly and that the total response time was adjusted to the estimated time. With the results obtained, several questions were improved, and a final questionnaire was designed, which provided a more appropriate structure and duration. In addition, in order to obtain greater participation, a link containing the same message on social networks was included.

Analysing the data by using PLS requires determining a minimum sample size in order to make the method robust and the results valid (Hair et al. 2017). Different authors such as Chin and Newsted (1999) recommend using the power test rather than the traditional method of 10 cases (Barclay et al. 1995) due to its low precision (Hair et al. 2017). To determine the minimum sample size, $G^{\star}$ Power 3.1.9.2 software was used (Faul et al. 2007), which is recommended by authors such as Hair et al. (2018), who suggest a minimum sample size of 56 cases for a power test of the minimum required 0.80 (Cohen 1988). In our research, these requirements are met for both categories of stakeholders considered, as 549 valid cases were obtained ( $80 \%$ students, $20 \%$ graduates), of which about $69 \%$ correspond to women and $31 \%$ to men.

\subsection{Measurement of variables and data processing}

Table 1 shows that 3 reflective items adapted to the scale of Mael and Ashforth (1992) and Balaji et al. (2016) were used for the identification measurement. For the loyalty measurement, 3 reflective items adapted to the scale used by Cervera et al. (2012) and Hennig-Thurau et al. (2001) were used. All the items were contextualized in the field of higher education. All constructs were measured using an ascending 11-point Likert scale, 0 (totally disagree) and 10 (totally agree). 
Table 1

Measurement scale

\begin{tabular}{cll}
\hline Factor & \multicolumn{1}{c}{ Indicator } & \multicolumn{1}{c}{ Item description } \\
\hline \multirow{3}{*}{ Identification } & Identification 1 & I feel that I am part of my university \\
\cline { 2 - 3 } & Identification 2 2 & $\begin{array}{l}\text { I consider the success of my } \\
\text { university as my own success }\end{array}$ \\
\cline { 2 - 3 } & Identification 3 & $\begin{array}{l}\text { I feel proud of the positive opinions } \\
\text { about my university }\end{array}$ \\
\hline \multirow{3}{*}{ Loyalty } & Loyalty 1 & $\begin{array}{l}\text { I would recommend my university } \\
\text { to relatives and friends }\end{array}$ \\
\cline { 2 - 3 } & & $\begin{array}{l}\text { If I had to continue with my } \\
\text { training, my university would be } \\
\text { my first choice }\end{array}$ \\
\cline { 2 - 3 } & Loyalty 3 & $\begin{array}{l}\text { If someone asked me for advice, I } \\
\text { would recommend my university }\end{array}$ \\
\hline
\end{tabular}

Source: Own elaboration based on Balaji et al. (2016); Cervera et al. (2012) and Kim et al. (2001).

The PLS-SEM method and the SmartPLS3 software V.3.2.7 were used to process the data and test the hypotheses. PLS-SEM is a multivariable analysis method whose main purpose is the prediction of dependent variables by estimating path models (Hair et al. 2018) and it also allows for the justification of moderating effects through multigroup analysis (Rasoolimanesh et al. 2017a; Hair et al. 2018). Multigroup analysis is performed by comparing the MGA (Henseler 2012) and permutations method, since they constitute non-parametric methods that have the advantage of not imposing data distribution. The permutations method has the advantage of not imposing hypotheses with direction, in addition to being considered the most reliable and recommended (Hair et al. 2018). These arguments justify that they are valid techniques for processing our research data.

\section{RESULTS}

Table 2 shows the average value of each variable. The average level of identification in students is between 7 and 7.5, while in graduates it is between 4.8 and 5.4. In relation to the level of loyalty, it reaches values between 6.8 and 7.5 in the student category, and in the graduate category it is between 3.6 and 3.7. Therefore, the level of identification and loyalty is higher in students than in graduates.

Table 2

Indicator measurement

\begin{tabular}{lcc}
\hline \multicolumn{1}{c}{ Indicator } & Students & Graduates \\
\hline Identification 1 & 7.523 & 5.422 \\
Identification 2 & 7.021 & 4.868 \\
Identification 3 & 7.231 & 4.806 \\
Loyalty 1 & 6.888 & 3.650 \\
Loyalty 2 & 7.424 & 3.890 \\
Loyalty 3 & 7.533 & 3.700 \\
\hline
\end{tabular}

Data processing using PLS-SEM involves analysing, first, the reliability and validity of the measurement instrument (Chin 1998). This involves assessing the individual reliability of the indicators on the latent variables through their loadings and the reliability of the scale or internal consistency can be measured through Cronbach's Alpha (CA), composite reliability (CR) and the Dijkstra-Henseler statistic (rho_A). For the validity analysis, it is necessary to assess convergent validity by means of the average variance extracted (AVE) and discriminant validity using the heterotrait-monotrait ratio (Hair et al. 2017).

In general, the individual loadings of the indicators must be greater than 0.7 to be considered acceptable (Hair et al. 2017). Different coefficients are used to test internal consistency: CA, which requires values greater than 0.7 (Nunnally and Bernstein 1994; Hair et al. 2017), CR, whose appropriate values are greater than 0.6 (Bagozzi and Yi 1988) or 0.7 (Chin 2010). Recent studies indicate that the rho_A coefficient requires values greater than 0.6 (Dijkstra and Henseler 2015). To establish convergent validity, the AVE must be greater than 0.5 (Chin 2010; Hair et al. 2017). To analyse discriminant validity, the heterotrait-monotrait ratio (HTMT) has been established as a better criterion than the Fornell-Larcker criterion and cross loadings, since these only work well with high sample sizes and with very heterogeneous loading patterns (Henseler et al. 2016a). Some authors suggest values below 0.85 (Kline 2015). As shown in Table 3 , the data are reliable and valid because its values conform to what was indicated above.

Table 3

Reliability and validity of the measurement instrument

\begin{tabular}{|c|c|c|c|c|c|c|c|c|}
\hline Factor & Indicator & Loading & t value & CA & CR & rho_A & AVE & HTMT \\
\hline \multirow{3}{*}{ 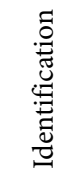 } & Identification 1 & $0.919^{* * *}$ & 92.667 & \multirow{3}{*}{0.919} & \multirow{3}{*}{0.949} & \multirow{3}{*}{0.920} & \multirow{3}{*}{0.861} & \multirow{3}{*}{ N/A } \\
\hline & Identification2 & $0.935^{\star * *}$ & 114.601 & & & & & \\
\hline & Identification 3 & $0.929^{* * *}$ & 106.567 & & & & & \\
\hline \multirow{3}{*}{ 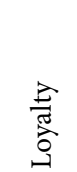 } & Loyalty1 & $0.942^{* * *}$ & 118.692 & \multirow{3}{*}{0.964} & \multirow{3}{*}{0.976} & \multirow{3}{*}{0.966} & \multirow{3}{*}{0.932} & \multirow{3}{*}{0.825} \\
\hline & Loyalty2 & $0.977^{\star * *}$ & 298.033 & & & & & \\
\hline & Loyalty3 & $0.978^{\star * *}$ & 348.898 & & & & & \\
\hline
\end{tabular}

$\mathrm{N} / \mathrm{A}=$ not applicable.

Once the measurement instrument has been analysed, the second step in order to test the hypotheses is to evaluate the structural model. For this, the collinearity analysis of the structural model must be carried out using the invariance inflation factor (VIF), statistical significance of the path coefficients, the $R$ coefficient, the $\mathrm{f}^{2}$ statistic and finally, the value of $\mathrm{Q}^{2}$ to determine predictive relevance (Hair et al. 2017).

Values with a VIF greater than 5 indicate the existence of possible multicollinearity problems. Table 4 shows a VIF of 2.434 , so the existence of such problems is at least 'a priori' excluded. The results obtained also show that identification influences loyalty positively and significantly in a context of institutional crisis $\left(\mathrm{H}_{1} ; \beta=0.379 ; \mathrm{p}<0.001\right)$. The $\mathrm{R}^{2}$ coefficient is 0.735 . Values between 0.50 and 0.75 are considered moderate 
in marketing academic research (Hair et al. 2017). Therefore, this allows us to indeed confirm Hypothesis 1 . The value of $\mathrm{f}^{2}$ is 0.196 and according to Cohen (1988), values between $0.15 \mathrm{y}$ 0.35 indicate an average effect. The rule to analyse predictive relevance is through the $\mathrm{Q}^{2}$ value, whose values must be greater than zero (Hair et al. 2017), Table 4 shows predictive relevance as it shows a value of 0.641

Table 4

Hypothesis 1 test

\begin{tabular}{lcccccc}
\hline \multicolumn{1}{c}{ Hypothesis } & $\begin{array}{c}\text { structural } \\
\text { VIF }\end{array}$ & $\begin{array}{c}\text { standardized } \\
\text { beta }\end{array}$ & $\begin{array}{c}\text { T value } \\
\text { (bootstrap) }\end{array}$ & $\mathbf{R}^{2}$ & $\mathbf{f}^{2}$ & $\mathbf{Q}^{2}$ \\
\hline $\begin{array}{l}\mathrm{H}_{1} \text { : Identification } \\
\text { - Loyalty }\end{array}$ & 2.434 & $0.379^{* * *}$ & 8.149 & 0.735 & 0.0196 & 0.641 \\
\hline
\end{tabular}

$\mathrm{n}=5.000$ sub-samples; ${ }^{\star} \mathrm{p}<0.05 ;{ }^{* *} \mathrm{p}<0.01 ;{ }^{* * *} \mathrm{p}<0.001$.

To carry out comparisons between groups using the permutations and MGA method, it is necessary to assess the invariance of the measurement instrument (MICOM) which consists of three steps. Step 1: to analyse the invariance of the configuration. Step 2: to examine the composite invariance. Step 3: to analyse the equality of measures (3rd) of variances (3b) (Hair et al. 2018). According to the results of the MICOM procedure shown in Table 5, we can establish partial invariance due to observing composite invariance. Partial invariance is a sufficient requirement to be able to compare the differences between groups using the permutations and MGA procedure (Roldán et al. 2016; Hair et al. 2018).

Table 5

Invariance of measurement instrument

\begin{tabular}{|c|c|c|c|c|c|c|}
\hline Step 2 & & & Step & & Step & \\
\hline $\mathrm{C}=1 \quad 5 \% \mathrm{C}_{\mathrm{u}}$ & Invar & Differences & $\begin{array}{c}\text { Confidence } \\
\text { level 95\% }\end{array}$ & Differences & $\begin{array}{c}\text { Confidence } \\
\text { interval 95\% }\end{array}$ & Invar \\
\hline
\end{tabular}

\begin{tabular}{|c|c|c|c|c|c|c|}
\hline 1 & 0.998 & Yes & 1.118 & {$[-0.205,0.226]$} & -1.582 & {$[-0.427,0.529]$} \\
\hline
\end{tabular}

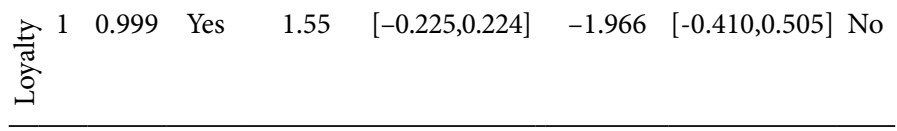

The results shown in Table 6 highlight the existence of significant differences between the categories of students and graduates in the relationship between identification and loyalty, both with the permutations method and with the Henseler PLS-MGA method $(\mathrm{p}<0.01)$. The relationship between identification and loyalty is more intense in the student category $\beta=0.461$ than in the graduate category $\beta=0.067$. The coefficient of determination $\mathrm{R}^{2}$ indicates a moderate effect as it is between 0.50 and 0.75 . Therefore, in view of these results, it can be concluded that statistical support is also obtained for Hypothesis 2.

Table 6 Multigroup hypothesis testing: Hypothesis 2

\begin{tabular}{|c|c|c|c|c|c|}
\hline & \multirow{2}{*}{$\begin{array}{c}\text { p-value } \\
\text { permutation }\end{array}$} & \multirow{2}{*}{$\begin{array}{c}\text { p-value } \\
\text { PLS-MGA }\end{array}$} & \multicolumn{2}{|c|}{ R2 } & \multirow{2}{*}{ Acceptance } \\
\hline & & & students & graduates & \\
\hline $\mathrm{H}_{2}:$ & $0.008^{* *}$ & $0.001^{* *}$ & 0.490 & 0.675 & Yes/Yes \\
\hline
\end{tabular}

\section{CONCLUSIONS}

The results of this study represent a useful contribution to the relationship of identification on loyalty of a higher education public institution in a crisis situation. They enable to validate empirically those relationships raised from the theory, to confirm and reinforce the results shown in other studies or to generalize results shown in business environments. This study has made an original contribution beyond what has been outlined so far, by exploring the existence of significant differences between the categories of students and graduates, and the results are also compared using two non-parametric methods (permutations and PLS-MGA).

The results show that there is a positive and significant relationship between identification and loyalty in an institutional crisis situation (Hypothesis 1), confirming what was found in previous studies (Kim et al. 2001; Cervera et al. 2012; Balaji et al. 2016; Gistri et al. 2018). On the other hand, the result of the multigroup analysis makes our contribution more relevant by revealing the existence of significant differences between the student and graduate category in relation to the direct effect of identification on loyalty and by comparing the results using two methods: the permutations method and the PLSMGA method. This multi-method that provides greater rigour and robustness to the results obtained has been developed to date in few studies and in other sectors (Henseler et al. 2016b; Rasoolimanesh et al. 2017a; Rasoolimanesh et al. 2017b). The effect of identification on loyalty is moderated by the stakeholder category, being much greater in students than in graduates in an institutional crisis situation (Hypothesis 2). Therefore, the study highlights the importance of identification on loyalty in the student group in a crisis situation as opposed to the graduate group.

In addition, the identification and loyalty indicator average in a crisis situation is higher in students (7.25 and 7.28 respectively) than in graduates (5.03 and 3.74 respectively). This may be a result of the fact that the University Rey Juan Carlos is a young university (founded in 1996), and that identification and loyalty bonds with its different types of stakeholders in a situation of institutional crisis could be more cognitive than affective. In other terms, it is a university that has not yet reached sufficient maturity to generate long-term emotional bonds with its graduates, which enable it to improve these values in the face of an adverse situation. 


\subsection{Practical implications}

Some important implications for the governors of universities can be derived from the results of this research. The results recognize the importance of identification to generate loyalty in an institutional crisis situation. Therefore, proper identification management with the university will cause attitudes and behaviours that are essential for the survival of HEIs in a crisis situation such as attraction, retention, temporary bonding or donations by their different types of stakeholders. In addition, the results show that the effects of the identification-loyalty relationship in a crisis situation are not similar between students and graduates, as there are significant differences between both stakeholder categories, and the connection is more intense in students than in graduates. This may be derived from the fact that graduates have only considered their time at the university as a mere mechanism to acquire a degree. It can also imply that student loyalty can be fake loyalty, originated only by behavioural and non-affective elements, where the greatest existing change barriers of degree studies in the public education sector, are represented by aspects of mobility or place of residence, which determine the choice of their study centre in a situation of institutional crisis.

A lower loyalty of graduates in a situation of institutional crisis can represent true loyalty, as there are greater change options for postgraduate studies such as, for example, the choice of a centre to take a Master's Degree. The fact that the relationship between identification and loyalty in a crisis situation is more intense in the student group than in the graduate group shows that university governors must be aware of the need to strengthen that relationship with students during their university period and establish different mechanisms to maintain them when they do not belong directly to it. An example of this could be to strengthen internal communication means and proceed to manage external communication in a comprehensive way.

\subsection{Limitations and future lines of research}

This study must be understood within the context in which it has been carried out, and is therefore subject to the limitations of the sample. Due to the fact that the model has been contrasted based on the opinions of students and graduates in a specific crisis period and in a particular public university, it can represent generalization problems to the university sector as a whole. Therefore, to overcome these limitations, we suggest expanding the sample to different countries, university contexts and other categories of stakeholders (such as teachers, administration and services staff, academic managers and society in general) as future lines of research, in order to achieve a greater consistency and generalization of the results.

\section{REFERENCES}

Ashforth, B.E., Harrison, S.H. and Corley, K.G., 2008. Identification in organizations: An examination of four fundamental questions. Journal of Management, 34 (3), 325-374.

Bagozzi, R.P. and Yi, Y., 1988. On the evaluation of structural equation models. Journal of the Academy of Marketing Science, 16 (1), 74-94.
Balaji, M.S., Roy, S.K. and Sadeque, S., 2016. Antecedents and consequences of university brand identification. Journal of Business Research, 69 (8), 3023-3032.

Barclay, D., Higgins, C. and Thompson, R., 1995. The Partial Least Squares (pls) Approach to Casual Modeling: Personal Computer Adoption Ans Use as an Illustration. Technology Studies, 2 (2), 285-234.

Bergami, M. and Bagozzi, R.P., 2000. Self-categorization, affective commitment and group self-esteem as distinct aspects of social identity in the organization. British Journal of Social Psychology, 39 (4), 555-577.

Bhattacharya, C.B. and Sen, S., 2003. Consumer-company identification: A framework for understanding consumers' relationships with companies. Journal of Marketing, 67 (2), 76-88.

Bloemer, J. and De Ruyter, K., 1999. Customer loyalty in high and low involvement service settings: the moderating impact of positive emotions. Journal of Marketing Management, 15 (4), 315-330.

Bundy, J., Pfarrer, M.D., Short, C.E., and Coombs, W.T., 2017. Crises and crisis management: Integration, interpretation, and research development. Journal of Management, 43 (6), 1661-1692.

Cachón-Rodríguez, G., Prado-Román, C. and Zúñiga-Vicente, J.Á., 2019. The relationship between identification and loyalty in a public university: Are there differences between (the perceptions) professors and graduates? European Research on Management and Business Economics, 25 (3), 122-128.

Casanoves, J., Kuster, I. and Vila, N., 2017. Student loyalty as a key to building a university brand. ESIC MARKET, 48 (3), 553-577.

Cervera, A., Schlesinger, M., Iniesta, M.Á. and Sánchez, R., 2012. Medición de la imagen de la universidad y sus efectos sobre la identificación y lealtad del egresado: una aproximación desde el modelo de Beerli y Díaz (2003). Revista Española de Investigación en Marketing, $16(2), 7-29$.

Chin, W.W., 1998. The partial least squares approach to structural equation modeling. Modern Methods for Business Research, 295 (2), 295-336.

Chin, W.W., 2010. How to write up and report PLS analyses. In: Handbook of Partial Least Squares. Springer, 655-690.

Chin, W.W. and Newsted, P.R., 1999. Structural equation modeling analysis with small samples using partial least squares. Statistical Strategies for Small Sample Research, 1 (1), 307-341.

Coelho, P.S., Rita, P. and Santos, Z.R., 2018. On the relationship between consumer-brand identification, brand community, and brand loyalty. Journal of Retailing and Consumer Services, 43, 101-110.

Cohen, J., 1988. Statistical power analysis for the behavioral sciences. 2nd ed. New Jersey: Lawrence Erlbaum Associates

Coombs, W.T., 2014. Ongoing crisis communication: Planning, managing, and responding. 4th ed. Thousand Oaks: Sage.

Dijkstra, T.K. and Henseler, J., 2015. Consistent and asymptotically normal PLS estimators for linear structural equations. Computational Statistics \& Data Analysis, 81, 10-23.

Dyntra, 2020. Universidades. Available at: https://www.dyntra.org/indices/universidades/

Ejerique, R., 2018. Cristina Cifuentes obtuvo su título de máster en una universidad pública con notas falsificadas. eldiario.es. Available at: https://www.eldiario.es/sociedad/Cifuentes-obtenido-publico-falseando asignaturas_0_752075026.html/ [Access March 21 $1^{\text {st }}$ 2019].

Ellemers, N., Kortekaas, P. and Ouwerkerk, J.W., 1999. Self-categorisation, commitment to the group and group self-esteem as related but distinct aspects of social identity. European Journal of Social Psychology, 29 (2-3), 371-389.

Faul, F., Erdfelder, E., Lang, A.-G. and Buchner, A., 2007. G* Power 3: A flexible statistical power analysis program for the social, behavioral, and biomedical sciences. Behavior Research Methods, 39 (2), 175-191.

Freeman, R.E. and Reed, D.L., 1983. Stockholders and stakeholders: A new perspective on corporate governance. California Management Review, 25 (3), 88-106. 
Fundación Mutua Madrileña, 2020. VII Estudio sobre Voluntariado Universitario 2019 [online]. Available at: https://www.fundacionmutua.es/Estudios.html

Gistri, G., Corciolani, M. and Pace, S., 2018. The interaction effect between brand identification and personal crisis relevance on consumers' emotional reactions to a fashion brand crisis. Journal of Global Fashion Marketing, 9 (3), 252-269.

Hair, J.F., Hult, G.T.M., Ringle, C. and Sarstedt, M., 2017. A primer on partial least squares structural equation modeling (PLS-SEM). 2nd ed. Thousand Oaks: Sage.

Hair, J.F., Sarstedt, M., Ringle, C.M., and Gudergan, S.P., 2018. Advanced issues in partial least squares structural equation modeling. Thousand Oaks: Sage.

Heffernan, T., Wilkins, S. and Butt, M.M., 2018. Transnational higher education: The importance of institutional reputation, trust and student-university identification in international partnerships. International Journal of Educational Management, 32 (2), 227-240.

Helgesen, $\varnothing$. and Nesset, E., 2007. What accounts for students' loyalty? Some field study evidence. International Journal of Educational Management, 21 (2), 126-143.

Hennig-Thurau, T., Langer, M.F. and Hansen, U., 2001. Modeling and managing student loyalty: An approach based on the concept of relationship quality. Journal of Service Research, 3 (4), 331-344.

Henseler, J., 2012. PLS-MGA: A non-parametric approach to partial least squares-based multi-group analysis. In: Challenges at the interface of data analysis, computer science, and optimization. Springer, 495-501.

Henseler, J., Hubona, G. and Ray, P.A., 2016a. Using PLS path modeling in new technology research: updated guidelines. Industrial Management and Data Systems, 116 (1), 2-20.

Henseler, J., Ringle, C.M. and Sarstedt, M., 2016b. Testing measurement invariance of composites using partial least squares. International Marketing Review, 33 (3), 405-431.

Iskhakova, L., Hoffmann, S. and Hilbert, A., 2017. Alumni loyalty: Systematic literature review. Journal of Nonprofit \& Public Sector Marketing, 29 (3), 274-316.

Johar, G. V, Birk, M.M. and Einwiller, S.A., 2010. How to save your brand in the face of crisis. MIT Sloan Management Review, 51 (4), 57.

Kang, J., Alejandro, T.B. and Groza, M.D., 2015. Customer-company identification and the effectiveness of loyalty programs. Journal of Business Research, 68 (2), 464-471.

Kim, C.K., Han, D. and Park, S.-B., 2001. The effect of brand personality and brand identification on brand loyalty: Applying the theory of social identification. Japanese Psychological Research, 43 (4), 195-206.

Kline, R.B. 2015. Principles and practice of structural equation modeling. 4 th ed. New York: Guilford.

Lafuente, A., Forcada, F.J. and Zorrilla, P.Z., 2018. El enfoque de marketing como filosofía de gestión de las universidades: un marco de trabajo para orientar su aplicación. Cuadernos de Gestión, 18 (2), 37-58.

Mael, F.A. and Ashforth, B.E., 1992. Alumni and their alma mater: A partial test of the reformulated model of organizational identification. Journal of Organizational Behavior, 13 (2), 103-123.

Marín, L. and Ruiz, S., 2007. La identificación del consumidor con la empresa: más allá del marketing de relaciones. Universia Business Review, (13), 62-75.

Nunnally, J.C. and Bernstein, I.H., 1994. Psychometric Theory. 3rd ed. New York: McGraw-Hill.

Oliver, R.L., 1999. Whence consumer loyalty? The Journal of Marketing, 63 (special issue), 33-44.

Palmer, A., Koenig-Lewis, N. and Asaad, Y., 2016. Brand identification in higher education: A conditional process analysis. Journal of Business Research, 69 (8), 3033-3040.
Pérez, F., Aldás, J., Aragón, R. and Zaera, I., 2017. U-Ranking 2017. Indicadores sintéticos de las universidades españolas. Fundación BBVA-Instituto Valenciano de Investigaciones Económicas.

Pucciarelli, F. and Kaplan, A., 2016. Competition and strategy in higher education: Managing complexity and uncertainty. Business Horizons, 59 (3), 311-320.

QS Quacquarelli Symonds Limited, 2019. QS Graduate Employability Rankings [online]. TopUniversities. Available at: https://www. topuniversities.com/university-rankings/employability-rankings/2020 [Access March 11 ${ }^{\text {st }}$ 2019].

Rasoolimanesh, S.M., Ringle, C.M., Jaafar, M. and Ramayah, T., 2017a. Urban vs. rural destinations: Residents' perceptions, community participation and support for tourism development. Tourism Management, 60, 147-158.

Rasoolimanesh, S.M., Roldán, J.L., Jaafar, M. and Ramayah, T., 2017b. Factors influencing residents' perceptions toward tourism development: Differences across rural and urban world heritage sites. Journal of Travel Research, 56 (6), 760-775.

Roldán, J.L., Cepeda, G., Henseler, J. and Ringle, C.M., 2016. Prediction-oriented modeling in business research by means of PLS path modeling: Introduction to a JBR special section. Journal of Business Research, 69 (10), 4545-4551.

Ruan, N.H., 2016. Brand loyalty in crisis: how does strong brand loyalty affect a company during crisis under different circumstances. Capstone for MS in Public Relations and Corporate Communication New York University.

Sallam, M.A. and Wahid, N.A., 2015. The effects of satisfaction and brand identification on brand love and brand equity outcome: the role of brand loyalty. European Journal of Business and Social Sciences, 4 (9), 42-55.

Schlesinger, W., Cervera, A. and Calderón, H., 2014. El papel de la confianza, la imagen y los valores compartidos en la creación de valor y lealtad: aplicación a la relación egresado-universidad. Revista Española de Investigación en Marketing ESIC, 18 (2), 126139.

Sen, S., Johnson, A.R., Bhattacharya, C.B. and Wang, J., 2015. Identification and attachment in consumer-brand relationships. Brand Meaning Management, 12, 151-174.

Stephenson, A.L. and Yerger, D.B., 2014. Does brand identification transform alumni into university advocates? International Review on Public and Nonprofit Marketing, 11 (3), 243-262.

Tajfel, H. and Turner, J.C., 1986. The social identity theory of inter group behavior in S. Worchel \& W.G. Austin (Eds.) Psychology of intergroup relations. 2nd ed. Chicago: Nelson.

Takaki, M., Bravo, R. and Martinez, E., 2015. La gestión de la identidad corporativa en la Universidad: análisis y consecuencias desde la perspectiva del profesorado. Revista Europea de Dirección y Economía de la Empresa, 24 (1), 25-34.

Times Higher Education, 2019. The World University Rankings [online]. Available at: https://www.timeshighereducation.com/rankings/europe-teaching/2019\#!/page/0/length/-1/sort_by/rank/sort_ order/asc/cols/undefined [Access May $11^{\text {st }} 2019$ ].

Tuškej, U., Golob, U. and Podnar, K., 2013. The role of consumer-brand identification in building brand relationships. Journal of Business Research, 66 (1), 53-59.

Universidad Rey Juan Carlos, 2018. Portal de transparencia [online]. Available at: https://transparencia.urjc.es/cifras/estudiantes.php [Access June 21 ${ }^{\text {st }} 2018$ ].

Xiao, N. and Lee, S., 2014. Brand identity fit in co-branding: the moderating role of $\mathrm{CB}$ identification and consumer coping. European Journal of Marketing, 48 (7/8), 1239-1254 